\title{
Collaboration of Parents and Care Professionals in Cases of Children Placed in Residential Care Homes - Parental Perspective
}

\author{
By Jana Rapuš Pavel
}

The paradigm of residential child care, providing education and care for children outside the family is changing worldwide. The emphasis is shifting from a narrow child-focused approach to a more child-and-family centred one, foregrounding the quality of collaboration between parents and everyone involved in the child's care. Several Slovenian studies draw attention to the difficulties of maintaining a collaborative partnership with parents that is based on trust and contact. We introduce the findings of a qualitative research study that included 32 individuals with children in different residential care homes throughout Slovenia. The aim of the study was to analyze the experiences and needs of the parents that could contribute to a better collaboration with the care professionals. The findings show that the parents emphasized the following as important for good collaboration: communication and dialogue, being informed, included and accepted as an important part of the team.

Keywords: collaboration, parents, residential child care, Slovenia, youth care professionals

\section{Introduction}

Any family can have difficulties when approaching collaboration with an institution where the child will reside, since the connotation of residential care is one of parental failure and potential power of the care professionals (Sinclair \& Gibbs, 1998, in Kendrick, 2008). This is why the attitude and approach of care professionals, namely social workers and youth care professionals ${ }^{1}$, is so important. Collaboration with the family is important throughout the child's stay in care outside the family in order to enable the child to have days outside the residential home (Geurts, Boddy, Noom, \& Knorth, 2012).

The placement of a child in a form of care outside the family affects the whole family. For parents it generally means pain and sorrow, and that they have to cope with their feelings of separation and loss on their own (Buchbinder \& Barequet-Moshe, 2011; Milligan \& Stevens, 2006; Rapuš Pavel \& Kobolt, 2008). Haagenstad (1992, in Buchbinder \& Barequet-Moshe, 2011) list 4 forms of family reactions to the removal of a child from home. The normal reaction of the parents and siblings is pain; there are also the feelings of

\footnotetext{
*Assistant Professor, University of Ljubljana, Faculty of Education, Slovenia.

${ }^{1}$ We use "youth care professional" as a translation of the Slovenian term "vzgojitelj", meaning the professional staff members who work directly with children and youths in residential care institutions in Slovenia.
} 
loss, sadness, emptiness, isolation, anger, anxiety, restlessness, worry and fear. In addition, the feelings of guilt and responsibility for the problem that led to the child's placement can also occur. The second reaction is the opinion of the parents that the child's placement in an educational institution is beneficial. The parents feel hopeful that the placement in care outside the family will result in the desired change in the child's behaviour. In the third case, it's the siblings who experience loss. In the fourth case, the placement of a child in care outside the family has a positive impact on the family. The parents report reduced tensions at home, fewer conflicts within the family and positive changes in parental roles.

In the new environment and by establishing new relationships the child has the potential for a change. But the child's parents also urgently need help and support. Keeping in contact is a prerequisite for establishing a sound partnership between the parents and care professionals. This can only be established with collaboration. Gradišar (2013) refers to various forms of collaboration for establishing and maintaining a relationship with the family. These include an exchange of information in written or spoken form; home visits, which help to nurture the relationship; parental visits to the institution in order to have insight into the educational practices taking place, and to create a dialogue; and the creation of structures which enable the parents to gradually reassume responsibility for the child (e.g. homework, organisation of free time during the weekends, medical visits, etc.). The important thing is that the youth care professionals focus primarily on what works and strengthens the family in question.

Care professionals face various obstacles when working with parents. Hornby (2000), whose focus is the teacher-parent relationship, identifies eight types of parental groups where cooperation is difficult. They consists of parents who do not support the educator's endeavours, who are not prepared to cooperate, who constantly complain, are hostile and threatening, parents whose expectations are either too high or too low, who abuse their child, who come from different cultural environments, are sensitive and vulnerable, and finally, those who have personal, relationship or family problems. Such categorisation of parents is quite rigid and labelling. In residential care situations, there is an associated risk that care professionals will stop trying to collaborate with the parents, assume the role of "substitute" parents and all the associated responsibilities, and exclude the parents in the belief that it is impossible to work with them. Razpotnik (2011) draws attention to this danger when she says that care professionals can quickly label the parents who live in difficult circumstances and have children that are perceived to be behaviourally difficult as being poor parents. If these parents refuse to participate or if they prematurely withdraw from the suggested forms of care, then they risk being accused of not striving in the direction of "good professional intervention". Professionals caring for children outside the family have a big impact on the family and the lives of the individuals within it; with this comes the responsibility to make the effort and contributions necessary to achieve changes. Čačinovič Vogrinčič (2006) says that the aim of working with the 
families is to discover better conditions for the life of the individual within and outside the family, to support the family so that it can be preserved, transformed or dissolved. Such goals can only be achieved with a good collaborative relationship, foregrounded in the family-centred approach, "which emphasizes a partnership between parents and service providers, focuses on the family's role in decision-making about their child, and recognizes parents as experts on their child's status and needs." (Law et al., 2003, in Geurts, Boddy, Noom, \& Knorth, 2012, p. 171)

\section{Methodology}

\section{Aim and Objectives of the Study}

The aim of our study was to analyse the experiences, needs and suggestions of parents who have children in residential care that could contribute towards a better collaboration with care professionals. The study examines the parental perception of the experience of collaborating with these professionals when placing the child and during the child's stay in care.

\section{Participants}

The parents were sent a letter describing the purpose of the study and inviting them to take part. The principals or the counselling services of the residential care institutions invited the parents to participate on our behalf. If they agreed, we obtained their telephone numbers and then arranged to meet them. The participants were 32 individuals from different regions of Slovenia, whose children (aged between 10 and 18) have stayed in 6 different residential institutions in Slovenia for at least 6 months and up to 3 years. We talked to 29 mothers and 3 fathers. ${ }^{2}$ At the time of the interview, 9 mothers were divorced and living alone or in an extended family. 7 mothers and 1 father were unemployed. From the interviews we know that the majority of the families are large: on average they have 3 children, the number of children ranging between 2 and 9 . In 4 cases these were immigrant families. In 5 cases mothers reported problems with domestic violence, in 3 cases disability, and in 4 cases problems with a partner's alcoholism, which was most often cited as a reason for divorce.

\section{Procedure}

\footnotetext{
${ }^{2}$ As is evident in the sample composition, we received substantially more responses to our invitations for interviews from mothers rather than fathers. While the article does not specifically highlight or discuss this gender division, it is clearly mothers rather than fathers who more often take up the intermediary role between the home and the institution, and presumably take on more concern for the children's upbringing.
} 
For the purposes of the study we conducted 32 semi-structured individual interviews. ${ }^{3}$ Draft conversations covered the following areas: a. General information and situation in the family; b. Experience of collaboration with professionals, professional services and institutions; c. Changes in the family during the placement and the child's stay in care; d. Suggestions (needs, expectations) for improving collaboration and involvement of the parents. The interviews lasted between an hour and an hour and a half. They took place in a quiet environment, either at the interviewee's home or in the institution, and were audio-recorded. The recordings were transcribed and analysed using a qualitative analysis. The method used was content analysis of data, which took place in the following sequence (Flick, 2002; Vogrinc, 2008): 1. organizing the material; 2. establishing units for coding; 3. coding; 4. selecting and defining relevant concepts and forming categories; 5. defining the categories, 6. establishing the final theoretical formulation.

This paper presents partial results only, focusing primarily on the parents' experiences of placement and collaboration with care professionals and the institutions they represent and on the suggestions by the parents for better collaboration. The next section presents the results of the qualitative content analysis (major and minor categories/themes), using statements by the parents as an illustration.

\section{Results and Discussion}

\section{Experiences of Parents at the Time of Placing the Child in a Residential Care Institution}

In Slovenia, the measure for placement into care may be imposed by a centre for social work practice or the court. Article 121 of The Marriage and Family Relations Act states that a centre for social work practice may on its own or in concert with the parents adopt the decision to place a child in care due to personal or behavioural problems that threaten the child's personal development (Zakon o zakonski zvezi in družinskih razmerjih [The Marriage and Family Relations Act], 2004). The placement in an institution providing education and care outside the family occurs when for various reasons the child can no longer stay at home and the measure becomes inevitable.

The parents included in our study addressed the issues of placement procedure and the relationship with care professionals at the time of placing the child. They associated the quality of the experience with the speed of the process. In nearly one third of the cases the parents told us that the process was dragging on, either because care professionals were delaying it (2 cases), or it became complicated because one of the parents ( 4 cases) or the child ( 3 cases) disagreed with it. The following statement by a mother involved in the process

\footnotetext{
${ }^{3}$ In collecting data, I collaborated with students attending the Social Pedagogy postgraduate course at the Faculty of Education in Ljubljana in the 2013/14 academic year. The organization and interview preparation took place under my mentorship.
} 
of placing a child in care illustrates this issue:

"Yes, everything dragged on a lot. We kept having team meetings and they were trying to persuade me again and again, then I saw there was no other way for this to work out, that this was the only option, because it got her to move away from a bad crowd".

In several cases, the negative experience with the placement was attributed to the cold and bureaucratic attitude of care professionals and the lack of information about the placement. For the parents this was an emotionally taxing situation and the decision to agree to place a child was not an easy one to make for most of them.

"This is a shock for the parents, all of a sudden a heavy load of problems is piled up on them, a bunch of professionals with whom you have to collaborate and it's very hard, because each one tells you something different, and you don't ever get the whole picture."

One of the key needs the parents highlighted in relation with the care professionals at the time of placement is to be listened to and heard and involved in the whole process.

\section{"I have to say that it took quite a while for them to hear us, but they see the situation from the other side because they are not emotionally involved."}

Working with parents when their child is placed in an institution is certainly one of the toughest and most sensitive areas of work. When analysing education in residential homes in Slovenia, Krajnčan (2006) draws attention to the power of the care professionals and to the fact that they have a free hand in deciding on the appropriate form of intervention used. Whether or not the measure for institutional care will be enacted greatly depends on the professional's attitude towards such education. Several parents emphasized that at the time of placement, they missed having a person who would talk with them realistically about education, present the good sides of a stay in care, as well as potential traps. They were unsure how to communicate with their child in the given situation. The parents told us that in these cases they needed professional support and more guidance, as well as a clarification of the issues that emerged in a given situation (what's "wrong" with the child, education, etc.). The lack of such support was particularly emphasised by the parents, who at the time of placement did not have anyone to support them or have an opportunity to talk to someone in order to release the feelings of guilt and other feelings when their child was taken into care.

"It's important for me that the care professionals show a certain degree of empathy, that they are respectful, that they understand that 
at the time of placement the parents are also in distress. At home I didn't have anyone left; luckily I got a good youth care professional. I liked that the attitude towards me was always fair, that I got the information of who to turn to, so that I knew who was "responsible" for my child when she was not at home. To me this was the most important thing as a parent, to have the feeling that my daughter is safe and well taken care of."

Buchbinder and Bareqet-Moshe (2011) showed in a study, which also included parents whose children were placed in residential care, that the parents see the placement of a child in care as necessary for the child especially in cases of aggressive behaviour and victimization of the parents, which is consistent with our findings. Lavi (2000, in Buchbinder and Bareqet-Moshe, 2011) notes that the mothers reported 4 basic feelings at the placement: pain, emptiness, anxiety and hope. In our case, the mothers who believed that a placement in residential care was necessary also reported relief, release, gratitude and the hope that the child will receive more opportunities and better living conditions than at home. In 7 cases, the parents faced aggressive behaviour by the children, who were experimenting with drugs, reported relief. Apart from the feelings of relief, the parents in their descriptions of the experience placed the main emphasis on feeling helpless, connected with feelings of guilt, as illustrated by the following statement of one mother:

"I felt guilty that I let her down. But I could not act differently. As I said, sometimes all I wish is to have more time to organise my thoughts, to think through my next step, to figure out what is best for my child. She would fall in with even worse company, she would not finish school. So I agreed and felt relieved when the placing was over."

Those mothers who considered the placement of the child as unnecessary expressed anger, bitterness, guilt and shame. In almost $2 / 3$ of the cases they spoke of feeling helpless at the possibility of losing their parental identity and status. Before placing their child in care, the parents faced feelings of incompetence, failure, guilt, anger and inability to provide care and education for their child.

\section{Collaboration with Youth Care Professionals during the Child's Stay in Residential Care}

An institution can collaborate with the parents in a variety of ways, such as via telephone conversations, parental meetings, parental visits at the residential care institution, visits by the care professionals at home, social meetings, cultural events, lectures for parents, therapeutic groups for parents, etc. It is very important to find some common educational goals and to pursue them (Gerič \& Horvat, 2000). In the framework of this collaboration, the parents in 
our study described the relationship with the youth care professionals working directly in residential care, inclusion and collaboration in their child's care and education as central.

The relationship with the institution during the child's stay in care was described by more than half of the parents (in 17 cases) as positive. Most frequently they described the experiences of warmth, friendliness, honesty, acceptance, reciprocity, being taken into account and good communication. Some of these aspects are illustrated by the following statements of 2 mothers:

"The relationship between us was characterised by a lot of honesty and trust because the youth care professionals gave me a sense of warmth, friendliness and sincerity, I felt all of them. I was hoping that they would stand by me and they did."

"We communicate well. They call me and ask if I agree. Most of the activities are planned by the institution and the child, but at monthly meetings they tell me, for instance, that the girl joined, let's say, this or that activity and ask me if that's okay. I really like this."

The experience of negative attitudes is frequently described by the parents as the experience of not being taken into account, being shown disrespect and judgement, which they are particularly sensitive to. The statement below indicates such lack of respect.

"What you need in a relationship is humanity, some respect for each other. From the beginning their approach was as if we were beating up the child, abusing him in who knows what ways, when they did not know anything about our family... the youth care professionals must first talk a bit with the parents to get to know them. They need to listen, there is no other way. You cannot just judge, it will only make things worse."

In a study of collaboration with the parents, Mikša (2013) explores the experiences of youth care professionals. She notes that they described collaboration with the parents as more challenging than that with the children. She highlights the importance of not having any pre-set expectations towards the parents. They often encounter an obstacle when they want to obtain the collaboration of the parents and on a relational level they find it difficult to work with parents who are angry and furious. In our study, the parents mention they most often experienced anger and dissatisfaction when they clashed with the youth care professionals about different views on education, and that in such cases, they often withdrew. They told us that this made them feel marginalized and disregarded and that they had doubts about the benefits of placing the child in residential care. Some pointed out that this situation of noncollaboration consequently reflected badly on the children, who became more 
manipulative and took advantage of various situations, which in turn weakened the authority of both the parents and youth care professionals.

"I told the youth care professionals and tried to prove to them that the child manipulates me and them, I told them the facts ... they replied that I do not need to worry at all, he's with them now, and that I should not worry at all"

In their descriptions of their experiences some parents also reveal the circumstances behind non-collaboration from their side. Non-collaboration is often associated with the experience of abuse of sincerity as described in the following statement by one mother:

"They only called me when there was something wrong with him. I then agreed to tell them what was going on at home. And what was happening at home they often used against him later on. Sometimes I doubted if I should even tell the truth. I was nevertheless sincere; only in the end I saw this was pointless."

In this context, parents drew attention to the following problems that discouraged them from collaborating; the youth care professional telling them too little about what is happening behind the closed doors of the institution, the excessive turnover of the staff, etc. On the issue of educational approaches and actions, the parents provided the following critical comments or observations: transmission of learned helplessness, poor or no educational measures, predominantly giving advice (this should be like this...), partial competence (dealing only with the symptoms, not solving the problem), and corroboration of negative behaviour. In the following statement, one mother draws attention to the lack of conversation with the child:

"And the youth care professional says: "Yes, we told him to do this and that, but it is not working. We'll try." But they have the time to write it all down? It is right that they should write it all down. But so many times I said they should talk to him, it's their job. He's a child who needs to be talked to."

The following statement by a mother also shows disagreement with the educational measures:

"I know that education is important and at the very beginning I always asked the professionals when my son would go to school, but they all assured me he will go once he earns it. I don't agree with this type of punishment."

In the cases when the parents were satisfied with the collaboration, they told us that the institution learned enough about their families, asked them for 
an opinion on everything when making decisions concerning the child and kept them informed. The youth care professionals first said positive things about the child, only then the negative. Collaboration was maintained regularly over the telephone and in meetings organized for the parents. They pointed out that good communication is crucial for collaboration, that youth care professionals provide them with support when there is a crisis or conflict situation they cannot resolve themselves.

The perspective of the parents from our findings can be compared with the perspective of the youth care professionals as identified by Mikša (2013). She reported that with regard to collaboration, they recognize three groups of parents: 1. parents who are aware that they must change their patterns of upbringing and behaviour, but do not know how and are open to collaboration; 2. parents who appear to be collaborating (they come to the meetings, express their opinion...) but at home they do everything in their own way; and 3. Parents who more openly refuse to collaborate, and often transfer their feelings of guilt, fear and pain to the child and thus damage the child. The phenomenon of "superficial participation" mentioned by the youth care professionals should perhaps not be condemned, but rather explored further (Grupper \& Jaffe, 2008). Asen (2007) describes some experiences by the parents that reveal some of the background for such "superficial participation". The relations between the family and professional services are often ruled by mistrust, denial, hostility and secrecy, which make collaboration more difficult. Professional services often start from a superior position and give parents advice on how to deal with their child. All parents want to be good parents and they find it difficult to accept criticism of how they are bringing up their child. They feel under attack and often deny there were any problems. We must understand that parents may not even believe that it would be possible to do anything with their child, because they themselves have already taken action and were unsuccessful. As a result, we can understand their apathy and lack of motivation to collaborate.

\section{Suggestions by the parents on how to improve collaboration with care professionals}

About half of the parents reported that they were satisfied with the collaboration, although some of them pointed out that initially they had low expectations ("youth care professionals cannot perform miracles") and ended up getting even more than expected.

"I am happy with the collaboration as it is. In fact, it's above my expectations. To me it's important to keep things moving forward, that my son is making progress, that he is improving, that we work together, exchange information, that we know what is going on with him."

The parents who repeatedly told us during the interview that they only have a low level of education were particularly modest when expressing their 
suggestions, needs and desires. They primarily expressed gratitude that the children were taken care of and said they would not change anything. Just over a third of the parents gave more concrete suggestions. These were aimed at improving the relationship with the youth care professionals, the child's education during the stay and the forms of working with parents. The parents underlined the following desired changes in attitude: the professionals should be more patient, honest, and open, they need to work with their "hearts", get deeper into the problem, be more "humane", respectful, they should not judge, they should listen to everyone involved and should not jump to conclusions. In connection with education, they advocated transparency, constant communication and joint decision-making. Some believed that the general societal attitude towards education is too permissive, children do not have enough obligations, sometimes sanctions and penalties should be used. They believe that the youth care professionals should be stricter and have more control over children (control their use of phones, limit negative social contacts, etc.).

The parents would primarily like to have more discussions and practical guidance on how to work more effectively with the child (for instance, a discussion on what to expect from the placement of a child in residential care, about the consequences of the child's experience of being placed in care, etc.). They would like the youth care professionals to be able to properly guide and involve them in the whole process. The importance of conversation is underscored in the following statement by a father:

"We should talk more, but not only just small talk. Before we heard from each other almost daily, but now they only call on Thursdays, asking me if he can come home or not. The communication is not good at all. At the beginning it was still more or less $O K$, we were in touch daily, but now it's like they do not care."

Parents want support, advice and guidance, especially in crisis situations. They want ongoing communication and involvement in making decisions concerning the child, which is also illustrated by the statement below:

"They should make an effort to work with the parents. At the last meeting they made me a bit angry because I was given quite a lot of criticism. It was about contacts with her mother and I mentioned they do too little about that. When I said that, it all went downhill, they said I live in the clouds and that this is not true."

In the context of improving collaboration, parents emphasize the following participatory forms of work: group meetings for parents where they would share experiences and advice, lectures for parents (on the most common parenting mistakes, how to react differently and better, advice on how to motivate a child for everyday tasks, such as domestic chores). It's important for them to be able to propose topics for lectures. They also suggest informal 
gatherings such as trips, where they could socialize with the parents of other children, in order to get to know each other better and to exchange experiences.

\section{Conclusion}

Many authors (Digman \& Soan, 2008; Dukes \& Smith, 2007; Geurts, Boddy, Noom, \& Knorth, 2012, 2012; Hobart \& Frankel, 2003; Jensen \& Jensen, 2011; Sternad, 2012) emphasize the importance of collaboration between the parents and professionals who are in any way involved in caring for and bringing up a child. In addition to directly caring for the child, the care professionals also represent a great potential for establishing a "positive" relationship with the parents. Dunst and Trivette have found that family-centred practices which "place families in central and pivotal roles in decision making about their lives, and their support needs", lead to the fact that " [a]s such, the family-centred professional operates as an "instrument" of the family, intervening in ways that a. are individualized, flexible, and responsive, and $\mathrm{b}$. support and strengthen family functioning" (Dunst \& Trivette, 2005, in Geurts, Boddy, Noom, \& Knorth, 2012, p.171). This ultimately depends on their expertise, communication and other skills, and their understanding of the functioning of the family in our society (Hobart \& Frankel, 2003).

In this paper we show the parents' experience of involvement and collaboration with the care professionals working in Slovenian residential care. It can be said that the parents identify the experience of collaboration with care professionals as central, especially when it comes to the child's upbringing. The findings show that more than half of the parents are satisfied with the experience of collaboration. A more detailed look at the data reveals that in most cases these parents were from lower socio-economic backgrounds. For them, the experience of good collaboration is closely associated with improved living conditions and better opportunities for their child enabled by the placement which in turn triggers relief, feelings of gratitude and meets their expectations concerning collaboration. It's precisely the underprivileged families with several problems who consider material support as a show of solidarity with their situation. This gives rise to affection, which is the basis for trust, and this trust is prerequisite for long-term gradual behavioural changes (Matter, 1999; in Čačinovič Vogrinčič, 2006).

The second group was formed by the parents who had more comments, observations and suggestions on how to improve partnership and collaboration. These parents drew attention to the lack of working with the whole family, of taking into account the distress upon the child's placement, poor communication and the exclusion from contact with the child and the child's education. Our findings suggest that it is understanding, sensitivity and consideration that the parents miss the most. Constable and Lee (2004, in Čačinovič Vogrinčič, 2006) talk about working with the families as working both from "outside" and "inside". It appears that the parents in our study also 
point out that need. It is important to understand that working with a family is a complex task, one that involves both the process of finding a solution as well as family relationships and the changes in the process of co-creating solutions. The work by the German author Helen Matter (1999, in Čačinovič Vogrinčič, 2006) provides us with the guidelines for collaborative work with the families, which emphasizes the helping relationship that must be established by care professionals in order to develop an alliance with the family and thereby an effective assistance. Although significant weight is given to the professionals' responsibility for establishing and maintaining the desired relationship and collaboration with the parents, it seems that on the other hand the contribution of the parents is also important and so is the awareness that it can sometimes be difficult to achieve. Digman and Soan (2008) point out that opening up channels of communication with parents is still a challenge. One of the major safeguards of this is probably the expertise of the care professionals, which includes specific knowledge in the area of providing care, upbringing and education outside the family and knowledge of the parents' needs, which this paper has hopefully helped to uncover.

\section{References}

Asen, E. (2007). Changing "Multi-Problem Families" - Developing a MultiContextual Systemic Approach. Retrieved on 5 March 2014 from http://bit.ly/1TqqxRB.

Buchbinder, E. \& Barequet-Moshe, O. (2011). Hope and siege: The experiences of parents whose children were placed in residential care. Residential Treatment for Children \& Youth, 28, 120-139.

Čačinovič Vogrinčič, G. (2006). Socialno delo z družinami [Social work with families]. Ljubljana: Fakuleta za socialno delo.

Digman, C. \& Soan, S. (2008). A Guide for Educational Professionals. London, California, New Delhi, Singapore: Sage Publications Ltd.

Dukes, C. \& Smith, M. (2007). Working with Parents of Children with Special Educational Needs. London: Paul Chapman Publishing.

Flick, U. (2002). Qualitative research- state of the art. Social Science Information, 41, $5-24$.

Gerič, D., \& Horvat, M. (2000). Delo z družino, centri za socialno delo in drugimi ustanovami [Working with the family, centres for social work practice and other institutions]. In M. Horvat (Ed.), Delo $z$ vedenjsko in osebnostno motenim otrokom in mladostnikom [Working with children and adolescents with behavioural and personality disorders] (pp. 20-28). Ljubljana: Zavod Republike Slovenije za šolstvo.

Geurts, E. M. W., Boddy, J., Noom, M. J., \& Knorth, E. J. (2012). Family-centred residential care: the new reality? Child and Family Social Work, 17, 170-179.

Gradišar, M. (2013). Stališča vzgojiteljev do aktivnega vključevanja staršev v proces vzgoje $v$ vzgojnih zavodih [The views of youth care professionals on the active involvement of parents in the care process of residential care homes]. Ljubljana: Pedagoška fakulteta.

Grupper, E., \& Jaffe, I. (2008). Residential staff's changing attitudes toward parents of children in their care: Rationale and healing effects on children, parents, and staff. 
Child Youth Care Forum, 37, 43-56.

Hobart, C., \& Frankel, J. (2003). A practical guide to working with parents. Cheltenham: Nelson Thornes Ltd.

Hornby, G. (2010). Improving parental involvement. London, New York: Cassell.

Jensen, E., \& Jensen, H. (2011). Dialog s starši [Dialogue with parents]. Ljubljana: Inštitut za sodobno družino Manami.

Kendrick, A. (2008). Black and minority ethnic children and young people in residential care. In A. Kendrick (Ed.). Residential Care: Prospects and Challenges (pp. 121-134). London: Jessica Kingsley Publishers.

Krajnčan, M. (2006). Na pragu novega doma: oddaja otrok v vzgojni zavod [On the doorstep of a new home: placing children into a residential care home]. Ljubljana: Pedagoška fakulteta.

Mikša, L. (2013). Sodelovanje s starši otrok v vzgojnih ustanovah [Collaborating with the parents of children in care institutions]. Ljubljana: Pedagoška fakulteta.

Milligan, I. \& Stevens, I. (2006). Residential Child Care: Collaborative Practise. London: Sage Publications.

Rapuš-Pavel, J. \& Kobolt, A. (2008). Alkoholizem v družini in doživljanje mladostnic, ki bivajo v vzgojnem zavodu [Alcoholism in the family and the experiences of female adolescents in residential care homes]. In M. Krajnčan, D. Zorc Maver and B. Bajželj (Eds.). Socialna pedagogika-med teorijo in prakso[Social pedagogy-between theory and practice] (pp. 97-121). Ljubljana: Pedagoška fakulteta Univerze v Ljubljani.

Razpotnik, Š. (2011). It is all up to me: access to education and the discourse of individual responsibility. Teorija in praksa [Theory and practice], 48(5), 14461465 .

Sternad, M. (2012). Socialnopedagoško sodelovanje $\mathrm{z}$ družinami $\mathrm{z}$ več problemi [Socio-pedagogical collaboration with families facing multiple problems]. Socialna pedagogika, 16, 437-468.

Vogrnic, J. (2008). Kvalitativno raziskovanje na pedagoškem področju [Qualitative research in the field of pedagogy]. Ljubljana: Pedagoška fakulteta.

Zakon o zakonski zvezi in družinskih razmerjih [The Marriage and Family Relations Act] (2004). Uradni list RS [Official Gazette of the Republic of Slovenia], št. 69/04 (24.06.2004). Retrieved on 5 January 2014 from http://bit.ly/1Ti3Y0A. 
